\title{
Mocorito y San Benito. La acción misionera y el poblamiento hispano en el sur de la provincia de Sinaloa 1592-1767.
}

\author{
Mocorito and San Benito. \\ Missionary action and Hispanic settlement \\ in the south of the Province of Sinaloa 1592-1767.
}

Raquel Padilla Ramos y Gilberto López Castillo*

Resumen: A partir del contraste de fuentes históricas este artículo ofrece un relato de la fundación de Mocorito como pueblo de misión y de San Benito como asentamiento alternativo de pobladores hispanos. Se da un seguimiento del proceso histórico de la misión y del contexto del poblamiento del entorno, hasta el establecimiento de un curato en San Benito al principiar la década de 1730. Una de nuestras fuentes primordiales para caracterizar a la misión y su vida son dos inventarios de la misión de Mocorito que dan cuenta de los bienes muebles religiosos de los templos respectivos que nos ayuda a evocar la época final de los jesuitas en Sinaloa. Consideramos que el seguimiento de la historia de una misión específica puede contribuir a la comprensión de la historia de la Compañía de Jesús en la Nueva España, a la vez de las relaciones de los miembros de la orden con los indígenas bajo su administración religiosa y con la población hispana del entorno.

Palabras clave: Mocorito, misión, Sinaloa, indios, inventarios de bienes religiosos

\footnotetext{
* Profesores-investigadores del Instituto Nacional de Antropología e Historia (INAH) en Sonora y Sinaloa respectivamente. Raquel Padilla Ramos es Coordinadora académica del Foro de Misiones del Noroeste de México y Gilberto López Castillo es miembro de la Societé International D’Etudes Jésuites. Email: raquelpadillaramos@gmail.com, email: gilbertohistory@gmail.com.
} 
Abstract: By contrast of historical sources, this article offers an account of the foundation of Mocorito as a mission pueblo and of San Benito as an alternative settlement of Hispanic residents. We follow the historical process of the mission and the context of the settlement around it, until the establishment of a parish in San Benito in the early 1730s. One of our primary sources for characterizing the mission and its life are two inventories of Mocorito's mission that provide a religious' goods detailed account of both temples, and that help us to evoke the final time of the Jesuits in Sinaloa. We believe that following the history of a specific mission can contribute to the understanding of the history of the Society of Jesus in New Spain, as well as the relations of the members of the Order with the Indians under their religious administration and with the surrounding Hispanic population.

Key words: Mocorito, mission, Sinaloa, Indians, inventories of religious goods

Recibido: 26 de mayo de 2017.

Evaluado: 28 de junio de 2017. 


\section{Introducción}

La misión jesuita de Mocorito, fundada en 1592 por el padre Juan Bautista Velasco, tiene diversas características que la hacen un tema relevante. Tomamos en cuenta primeramente que es posible realizar acercamientos historiográficos gracias a la existencia de testimonios diversos aunque principalmente jesuíticos sobre la misión. En segundo término, que su templo misional se mantiene en pie y abierto al culto, y es el principal referente del actual Mocorito, donde asimismo se custodia gran parte de la memoria histórica de todo el antiguo río Évora; y en tercero que nos permite reconsiderar el planteamiento de la misión como un espacio cerrado en el que supuestamente solo había indígenas, y donde los demás miembros de la sociedad novohispana eran excluidos. En este caso estamos de acuerdo con la propuesta de Bernd Hausberger (2015) quien explica que una característica de la misión jesuítica novohispana, a diferencia del modelo guaranítico, fue que no se desarrolló por separado y aislada de la colonización civil, y que por el contrario su avance corría paralelo y en una compleja interdependencia con la expansión militar, minera, ganadera y agrícola del sistema colonial.

\section{Antecedentes históricos}

La misión de Mocorito formó parte de la Provincia Mexicana de la Compañía de Jesús y fue uno de los primeros campos de evangelización en la provincia de Sinaloa, habiéndose integrado con diversos pueblos y rancherías del río, también llamado Mocorito. ${ }^{1}$ En esta región la población indígena cultivaba maíz de temporal, calabazas, chile y frijol, a la vez que realizaban temporalmente recolección de péchitas ${ }^{2}$ del mezquite (Prosopis glandulosa), y que del mezcal (Agave angustifolia) se hacían vino y miel. La producción de licor debió ser de consideración, ya que los misioneros reportaban que frecuentemente tenían que lidiar con el "vicio" de la embriaguez. La recolección de pitayas (Stenocereus queretaroensis), que los padres conocieron como higos de la India, era fundamental para la supervivencia de las sociedades indígenas en tiempos en que no se cosechaba. Asimismo, se sembraba algodón u otras plantas que permitían la elaboración de mantas tejidas o hiladas (Pérez de Ribas, 1992 [1645], p. 5-9).

El río Mocorito era el límite meridional de la "cultura Huatabampo", desarrollada entre el 200 a.C. y el 700 d.C. Su confín norteño era el río Yaqui y en términos generales coincide con un amplio territorio donde se hablaba la lengua que los colonizadores llamaron cahita y hoy se reivindica como yoreme (Gerhard, 1996, p. 339 y López, 2010, pp. 43-57). Las investigaciones han identificado que aquí se realizaba por los pobladores originarios una cerámica roja y fina antropomórfica o en forma de botellones. Ellos, los huatabampo, eran los antepasados de yaquis y mayos con quienes sin duda los mocoritos mantuvieron relaciones.

\footnotetext{
${ }^{1}$ La etimología de la palabra es dudosa. De acuerdo al cronista Héctor R. Olea, su origen es cahita y se compone de macori, que deviene en macorihui, es decir macoyahui, que es una forma nominativa de los mayos. Sin embargo, en lengua mayo makojiawi significa "hachazo" (sonido del hacha, más precisamente). Moko, en cambio, significa "chamizo" y el sufijo to indica lugar en el mayo del sur, no tanto en el que se habla en Sonora, donde se emplea más el sufijo po, de modo que podríamos estar ante un "lugar de chamizos". Por otro lado, señala Eustaquio Buelna que proviene de mukirata, "lugar de muertos" (Monografia de Mocorito, 1990).

${ }^{2}$ Vaina del mezquite.
} 
Poco después de la conquista realizada por las tropas de Nuño de Guzmán en 1531 la población indígena del río Mocorito fue dada en encomienda al soldado portugués Sebastián de Évora, motivo por el cual el río tomó su nombre. Continuó como encomendero Pedro de Tovar, quien permaneció hasta la época de Francisco de Ibarra quien lo ratificó en su nombramiento (Gerhard, 1996, p. 340).

Es importante advertir que fueron los indígenas mocoritos quienes dieron la bienvenida a los primeros padres jesuitas enviados a la provincia conocida como Sinaloa, que fueron Martín Pérez y Gonzalo de Tapia, en julio de 1591. Ello debido a que su pueblo se encontraba en un lugar intermedio del antiguo camino de la costa que comunicaba los dos asentamientos hispanos que en aquel momento eran los más septentrionales en la franja costera del Pacífico, es decir, las villas de San Miguel de Culiacán y San Felipe y Santiago de Sinaloa.

El misionero y cronista de la orden jesuita Andrés Pérez de Ribas relata que dos vecinos de la villa de San Felipe y Santiago de Sinaloa pasaron a recibirlos acompañados de indios amigos que habían sido evangelizados por los franciscanos poco después de la conquista de Francisco de Ibarra en 1564. El encuentro se dio en el pueblo de Capirato, al norte de Culiacán, mientras que más adelante, tres leguas al sur del río Mocorito en un punto conocido como El Palmar, recibió el hijo del cacique de Mocorito a los padres, acompañado de niños del pueblo que fueron allí mismo bautizados (Pérez de Ribas, 1992 [1645], p. 84).

La ruta habría seguido por tierras del río Évora, deteniéndose los padres a ofrecer misa en el pueblo de Orabato, donde había una antigua iglesia de madera y paja, arribando el 6 de julio de 1591 a la villa de San Felipe y Santiago de Sinaloa. El testimonio del jesuita es por supuesto lleno de solemnidad, registrando el gusto de los indios y el gran recibimiento para los padres Tapia y Pérez, que fueron acompañados hasta la villa de Sinaloa (Pérez de Ribas, 1992 [1645], p. 84. Alegre, 1956, p. 365).

Con el paso de los años y el progreso de las misiones y del colegio de Sinaloa, Mocorito fue la misión más meridional de la provincia y lugar de paso en el "Camino a la Sonora" para misioneros jesuitas, religiosos seculares, soldados, comerciantes y todo tipo de personas que entraban al área misional, o volvían a la "Tierra afuera". 3 De igual modo fue punto de paso de mercancías, cartas, objetos, noticias, enfermedades y metáforas, y punto de inicio de la conformación del ser noroesteño (Fig. 1).

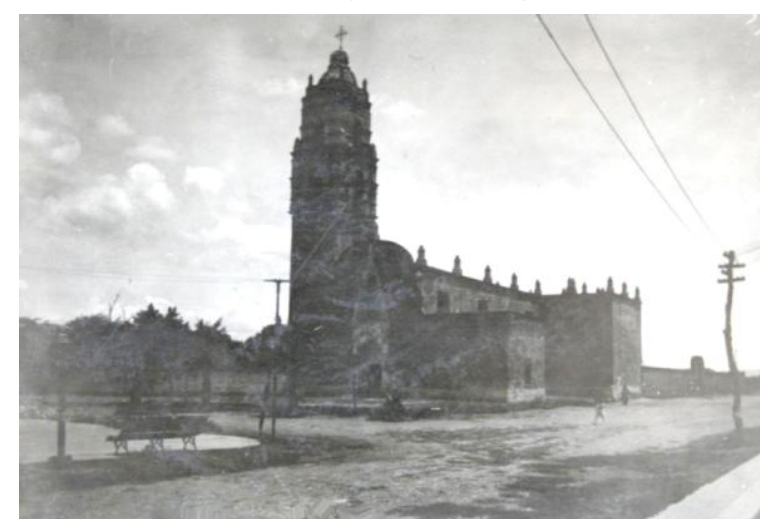

Fig. 1. Templo de la Purísima Concepción de Mocorito, 1922 (Carrillo Rojas et.al., 2012).

\footnotetext{
${ }^{3}$ Tierra afuera era un concepto utilizado en la época en contraposición al de "Tierra adentro", que era como se apreciaba desde el punto centralizado en la ciudad de México. El camino de la costa que proveniente de la ciudad de México al llegar a Nayarit se dirigía paralelo al mar, sobre la franja costera, cruzaba desde Chiametla hasta Sonora y era llamado así, dependiendo del lugar en el que se estuviera.
} 


\section{Época fundacional}

Se considera al padre Juan Bautista Velasco como el fundador de la misión de Mocorito. Nació en la ciudad de Oaxaca en 1564, teniendo una formación de casi un lustro de filosofía, previa al ingreso a la Compañía de Jesús en $1580 .{ }^{4}$ Sus primeros años como miembro de la orden los desarrolló en Guadalajara, sin embargo las diferentes fuentes consignan su petición a los superiores de ser enviado a misión en los momentos que se iniciaba el trabajo pastoral en Sinaloa (O`Neill y Domínguez, 2001, pp. 39183919 y Gutiérrez Casillas, 1975). ${ }^{5}$

Pérez de Ribas consigna la llegada de dos nuevos padres a la misión de Sinaloa, que lo fueron Alonso de Santiago y Juan Bautista Velasco:

El padre Juan Bautista, que era muy buena lengua Mexicana y trabajó con grande loa por muchos años hasta el fin de su vida en esta provincia se le encargaron los pueblos de Mocorito, Bacuberito y Orabato, con sus visitas, donde había algunos indios más ladinos con la cercanía y trato de los culiacanenses, que eran de ayuda en aquella conversión (Pérez de Ribas, 1992 [1645], pp. 44-55).

De lo que no hay consenso es de la fecha del inicio de la misión en Mocorito, que tradicionalmente se conmemora en relación al día de San Miguel de 1593, pero de la que sin embargo diversas fuentes nos remiten al menos a 1592, que nosotros consideramos como más plausible en virtud de que si los testimonios no ofrecen certezas, al menos sí hablan de Juan Bautista Velasco en los principios de la misión de Sinaloa y particularmente de este año. Uno de los testimonios expresados en marzo de 1592 por el padre Pedro de Avellaneda al general Aquaviva consigna que se había dispuesto de tres padres para ir a Sinaloa, estando entre ellos Juan Bautista Velasco. ${ }^{6}$ En agosto del mismo año Gonzalo de Tapia también refería de cierta indisposición de Juan Bautista Velasco para las tareas misionales -es decir que ya estaría en Mocorito-, lo que reflejaba en última instancia la desilusión de Tapia respecto de que los apoyos de nuevos padres en las misiones careciesen de experiencia fuera de los colegios. ${ }^{7}$

A tono con lo dicho por Tapia, Pérez de Ribas lo caracterizó como de "complexión muy delicada y achacosa", 8 aspectos que sin duda después de una trayectoria de poco más de dos décadas, pudieron ser subsanados por el éxito de su misión entre los mocoritos. Paradójicamente, en la misma Historia de los triumphos de nuestra santa fee se correlaciona la primera construcción de las iglesias misionales en el río Sinaloa a instancias de Hernando de Villafañe al iniciar el siglo XVII, con la primera construcción

\footnotetext{
4 “Catálogo parcial de la provincia de México, año de 1582”, en Félix Zubillaga (ed.), 1959: 108.

5 "El padre Diego de Avellaneda a nuestro padre Aquaviva, México, $1^{\circ}$ de marzo de 1592", Aquaviva, Archivum Romanum Societatis Iesu (ARSI), México 16, Historia 1565-1600, f. 51.

6 "El padre Diego de Avellaneda a nuestro padre Aquaviva, México, $1^{\circ}$ de marzo de 1592", ARSI, México 16, Historia 1565-1600, f. 51. Los otros dos eran Alonso de Santiago y el coadjutor Nicolás Gallardo.

${ }^{7}$ El padre Gonzalo de Tapia al general Claudio Aquaviva, ARSI, México 16, Historia 1565-1600, 7 de agosto de 1592: 107-108v. y Pérez de Ribas (1992 [1645], pp. 228-231). Luis González Rodríguez y María del Carmen Anzúrez consignan que Juan Bautista Velasco "En 1592 fue destinado a Sinaloa junto con el padre Alonso de Santiago. El superior, Gonzalo de Tapia, lo señaló como misionero de Mocorito y sus pueblos de visita" (González y Anzúrez, 1996: 173). Lo mismo se consigna en E. Oneill y Domínguez, (2001, pp. 3918-3919). Pérez de Ribas no es claro en este sentido.

${ }^{8}$ Pérez de Ribas, 1992 [1645]: 228-231.
} 
de las mismas entre los pueblos del río de Sebastián de Évora, que según el testimonio, "también salieron vistosas" (Pérez de Ribas, 1992 [1645], p. 99).

De hecho no es justo hablar en abstracto de la "Misión de Mocorito" al comienzo de la evangelización jesuita, porque en primer lugar, originalmente era un conjunto de pueblos que a partir de la conquista española se identificó como Valle del Évora, debido al soldado portugués que los recibió como encomienda. Dicha misión se conformó por indígenas que fueron reunidos y que provenían de diversas rancherías, todas ellas ribereñas. Mocorito fue de origen un punto de confluencia debido a su localización en el camino real y propiamente a ser un lugar central respecto de toda una comarca que iba desde el mar hasta las faldas de la Sierra Madre Occidental, donde con el paso del siglo XVII fue estableciéndose un nutrido vecindario español que recibía en la misión los elementos del cristianismo tal y como si fuera una parroquia (Fig. 2).

El informe de Juan Ortiz Zapata (1678) habla de cuatro lenguas distintas en el pueblo de Mocorito, al igual que en el de Bacubirito que fueron los puntos donde habrían sido congregados los nativos en la primera mitad del siglo XVII. ${ }^{9}$ Todavía en 1744 el padre Bernardo de Mercado explicaba que el pueblo de Bacubirito se compuso de bacubiritos, terahuitos y

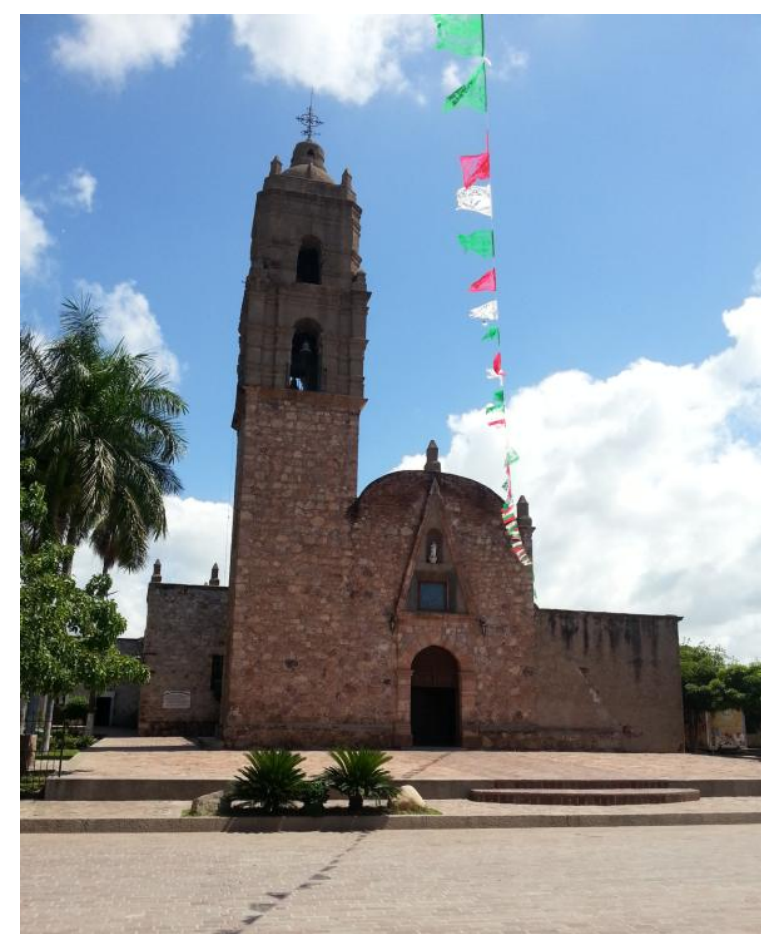

Fig. 2. Templo de la Purísima Concepción de Mocorito. bacapas (Burrus y Zubillaga, 1982, pp. 58-60). Los misioneros usaron el idioma mexicano como lengua franca, pero debido a la gran diversidad étnica, también procuraron aprender las lenguas originarias (Pérez de Ribas, 1992 [1645]. p. 22).

Existen diversos testimonios tempranos que refieren a un río habitado de forma extensiva por la población nativa desde su mismo nacimiento en las faldas de la sierra hasta su desembocadura. Un lugar importante en este panorama lo ocupa el mapa " $\mathrm{Cu}$ liacanae Americae Regionis Descriptio" de Abraham Ortelio de 1579, en cuya parte septentrional tenemos al "fluvius San Sebastiani", un pequeño río que se desdibujaba en la desembocadura (Mapa 1).

Una de las mejores descripciones geográficas de los inicios de la presencia jesuítica proviene de "La relación de Nuestra Señora de Cinaloa", que ha sido adjudicada al misionero Martín Pérez. Comenzaba así:

\footnotetext{
9 "Relación de las misiones que la Compañía tiene en el Reyno y provincia de la Nueva Vizcaya, en la Nueva España, hecha el año de 1678 con ocasión de la visita general de ellas que por orden del padre provincial Thomas Altamirano hizo el padre visitador Juan Ortiz Zapata, de la misma Compañía", Archivo General de la Nación México (AGN), Misiones 26, fs. 266-267.
} 
Cuéntase esta provincia por ríos, porque las más de las poblaciones están a la rivera de ellos y corren de la serranía grande de los tepehuanes y van a dar a la mar del sur. El primero se llama de Sebastián de Évora, porque se llamaba así un hombre que los tuvo a cargo. Dista este río de México cerca de 300 leguas. Hay en él cinco de pueblos de cristianos: el primero se llama San Juan Bautista de Orabato, el segundo San Jusepe de Onatoato, el tercero San Mateo Motzocarito, el cuarto Nuestra Señora Mahotoato, el quinto la conversión de San Pablo Mocorito. Habrá en estos cinco pueblos más de 1100 personas baptizadas, sin otras que faltan y hasta 160 casados in facie eclesíae. Fuera de estos pueblos teníamos en esta comarca otros dos pueblos a la orilla del mar, donde teníamos más de 600 baptizados y más de otros 100 casados; no damos ya ahora doctrina a estos pueblos, porque pertenecen a la provincia de Culiacán (González y Anzúrez, 1996, pp. 196-197).

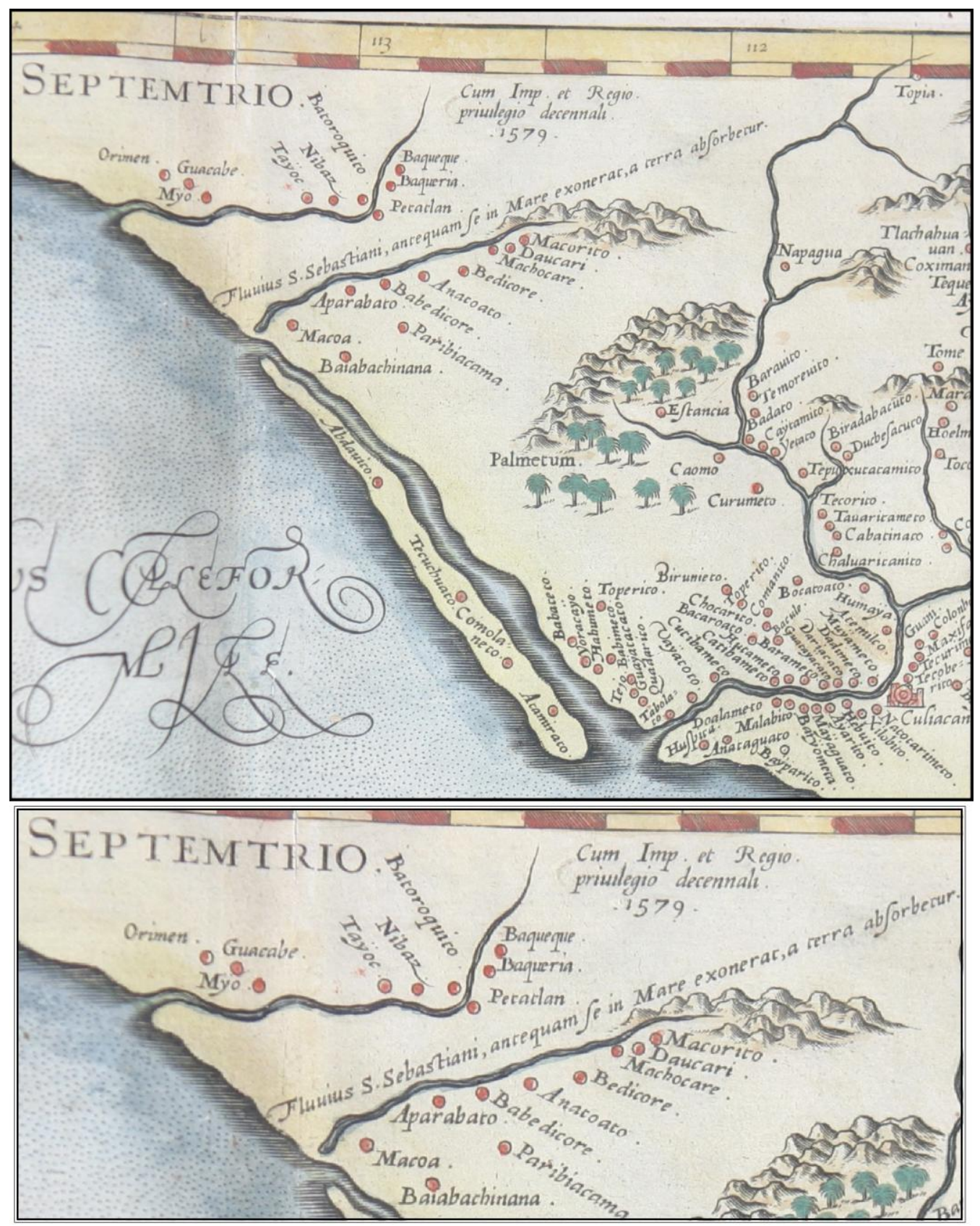

Mapa 1. "Culiacanae, Americae Regionis Descriptio” (Ortelio, 1579). Detalle de pueblos del río Évora. 
En unas cuantas líneas, su autor nos posiciona en relación a la ciudad de México 300 leguas, a la vez que expresa el típico patrón de poblamiento promovido por los jesuitas que para entonces ya habrían realizado una primera ronda de agrupamientos. Los reordenamientos territoriales afectaron a muchos de los asentamientos indígenas antiguamente dispersos, para optimizar el aprovechamiento de las tierras ribereñas. Los nombres cristianos de los asentamientos y los registros de bautismos y matrimonios marcan la nueva etapa del río Évora bajo administración jesuítica.

La "Relación de Cinaloa" es uno de los primeros testimonios de una empresa misionera que se prolongaría entre 1592 y 1767, destacando el rol central del pueblo de Mocorito al que acudían los indios al tañer de las campanas. A pesar de todo, Mocorito era asimismo un pueblo que había permanecido pacífico, en oposición a los guasaves que se habían insurreccionado estando en ellos los padres Hernando de Villafañe y Hernando de Santarén. El papel del padre Velasco y su dominio de la lengua fue clave en los inicios de la misión de Sinaloa y particularmente en el río Mocorito que sobrellevó sin grandes sobresaltos.

La conquista espiritual realizada en Sinaloa, el Fuerte y Mocorito, se caracterizó por una exacerbada violencia ejercida por la fuerza militar de la monarquía hacia los pueblos originarios que utilizaron como justificación ideológica la extirpación de las idolatrías y supersticiones (Borrero Silva, 2004, p. 49). Por algo Luis Navarro advierte que gracias al Capitán y al "esfuerzo, arrojo y abnegación de un centenar de soldados, misioneros y vecinos", los españoles pudieron señorear del río Mocorito al río Yaqui, pero también puntualiza en que no todo fue en desarmonía; y que se tiene registro, por ejemplo, de que el padre Francisco de Sepúlveda se alimentaba de hierbas que recogía porque prefería dar sus bastimentos a los naturales de Chicorato y Mocorito (Navarro, 1992, pp. 205 y 219). Cabe destacar que el padre Juan Bautista Velasco permaneció entre los mocoritos durante dos décadas, desde la fundación de la misión en 1592 hasta su muerte el 29 de julio de 1613, de tal forma que al igual que otros padres fundadores de la misión de Sinaloa, como Hernando de Villafañe y Martín Pérez en su carácter de "padre lengua", dejó un legado que sería referente entre los mismos jesuitas que le continuaron (Alegre, 1958, pp. 242-243).

No tenemos por ahora el rastreo de cómo fue el proceso de concentración de los pueblos iniciado por el padre Velasco que devino en que el de Mocorito se convirtió en el único asentamiento misional del río que tuvo una estrecha relación con la misión de Bacubirito, hacia la sierra, pero en este caso sobre el alto curso del río Sinaloa o Petatlan. Las cuatro lenguas distintas en cada uno de estos pueblos registradas por Juan Ortiz Zapata en 1678 son una muestra de aquel proceso llevado hasta sus últimas consecuencias. $^{10}$

\section{Misión y entorno}

La renta de recuas de mulas y caballos fue una de las actividades económicas que realizaban los indígenas y que en el contexto de relaciones entre éstos y los capitanes del presidio de Sinaloa llevó a situaciones de conflicto. Particularmente en 1672

\footnotetext{
${ }^{10}$ AGN, Misiones 26, fs 241-269v, "Relación de las misiones que la Compañía tiene en el Reyno y provincia de la Nueva Vizcaya, en la Nueva España, hecha el año de 1678 con ocasión de la visita general de ellas que por orden del padre provincial Thomas Altamirano hizo el padre visitador Juan Ortiz Zapata, de la misma Compañia”, AGN, Misiones 26, fs 241-269v.
} 
hubo una situación de crisis entre indígenas de los ríos Mocorito, Sinaloa y Fuerte, con motivo de los abusos del capitán Mateo Ramírez de Castro, cuyas expresiones de descontento llegaron hasta la Audiencia de Guadalajara por medio de tres indígenas de la nación Mocorito que fueron acompañados por el protector de indios de Sinaloa.

Los motivos de queja tenían en primer lugar el hecho de que el capitán Mateo Ramírez de Castro y los milicianos del presidio solían utilizar los caballos de los indios de Mocorito en remuda, dándoles maltrato a las bestias, y pagando a los indios "unas veces dos reales y otras nada", a la vez que utilizaban la fuerza de trabajo indígena mediante repartimiento laboral obligatorio, mismo que remuneraban en mercancías y no en efectivo como se estipulaba. Además y como una muestra del mecanismo de poder ejercido mediante el terror y la violencia, los mocoritos denunciaron que el capitán mandó poner un palo de mezquite (o bramadero) en la plaza de San Felipe y Santiago de Sinaloa. ${ }^{11}$ La queja fue escuchada y atendida en la Audiencia de Guadalajara, con lo que los indios de Sinaloa establecieron una tradición de lucha. Cabe decir, que las quejas sobre la violencia ejercida contra los indígenas no se limitaban al capitán de Sinaloa, sino que también incluía a los padres misioneros, dados a utilizar el castigo mediante azotes, a atusar (rapar las cabelleras) a los indígenas y los azotes, y a utilizar sin paga el trabajo de las mujeres en la molienda del trigo (Navarro, 1992, pp. 158-164) (Mapa 2).

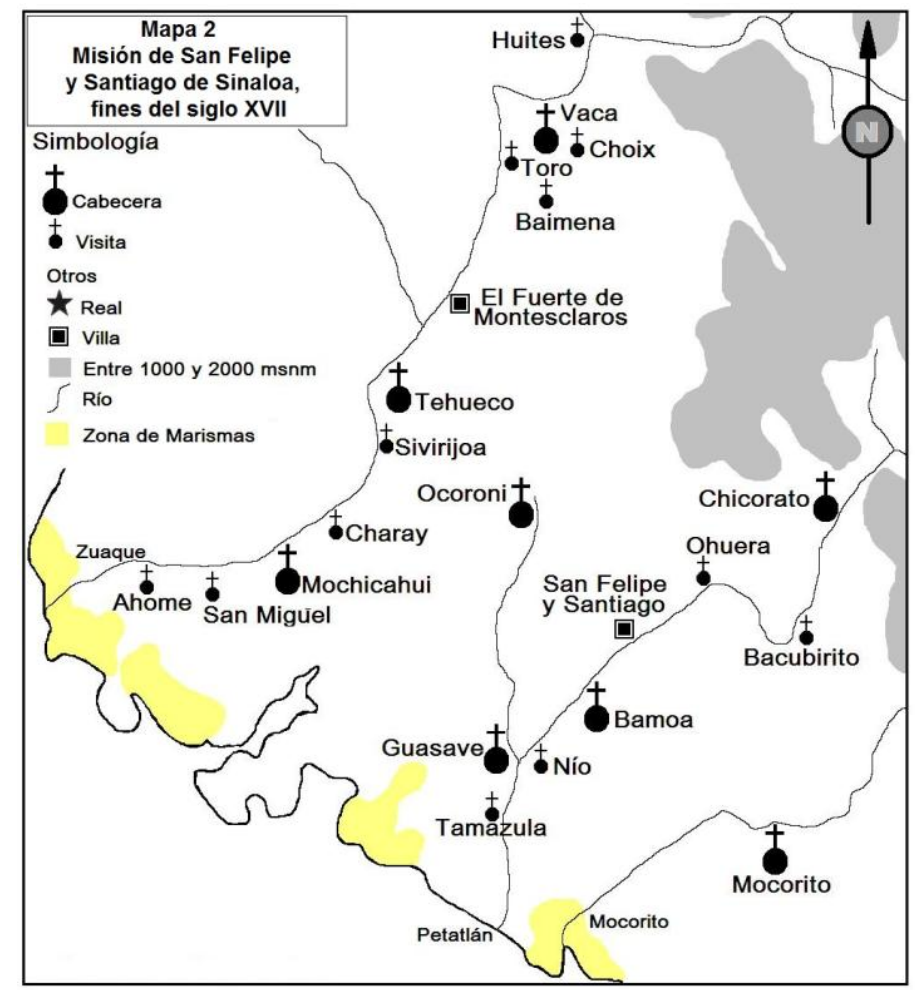

Mapa 2

Más de medio siglo después, el padre visitador Juan Antonio Balthasar registraba que la misión de Mocorito contaba entre sus bienes con tierras de sembrar, mulada y recua, así como un poco de ganado mayor y caballada. ${ }^{12}$ El padre Salgado fue más pun-

\footnotetext{
11 “Testimonio de los indios Juan Baptista y Martín Juárez, del pueblo de Mocorito, en la provincia de Sinaloa", en Archivo de la Real Audiencia de Guadalajara, Biblioteca Pública de Jalisco, Ramo Civil, exp. 8-15-111, fs. 1-6.

12 "Visita de la provincia de Sinaloa, hecha por el padre visitador general Juan Antonio Balthazar, en los años de 1743 y de1744”, en Burrus y Zubillaga, 1986: 114-115.
} 
tual, registrando que en 1755 había 399 cabezas de ganado mayor, 59 de mulada y 122 de caballada. ${ }^{13}$

Paralelamente transcurre el poblamiento hispano en el entorno misional: ranchos y estancias de ganado mayor, dependientes de forma directa para su administración de la Villa de Sinaloa, pero que por la cercanía a la misión de Mocorito van quedando registrados en los libros de la misión. Una fuente alterna donde se van consignando los ranchos, sitios y estancias tiene que ver con las composiciones de tierras, en cuyos expedientes encontramos información de los siglos XVII y XVIII. El problema que tenemos actualmente es que el tipo de información sobre estos asentamientos no permite hacer una cronología fina, de tal forma que solo contamos con las tendencias que en 1767 alcanzaba los 31 asentamientos dispersos por todos los vientos del entorno misional del río Mocorito o valle del Évora (Ver anexo 1) (Rodríguez Gallardo, (1975) [1750], pp. 77-78).

Este ámbito de gobierno tuvo una denominación específica como alcaldía mayor de San Benito a partir de la creación de la Gobernación de Sinaloa y Sonora, quedando bajo su jurisdicción desde el mar hasta las montañas de Sarutato y Santiago de Caballeros (Gerhard, 1996, p. 341). Cabe decir que la creación de la alcaldía mayor fue aparejada a la de un curato en San Benito con el que se buscaba atender a la población hispana dispersa en el entorno. Un asentamiento que durante sus primeras dos décadas vivió momentos de incertidumbre, ante la negativa de los pobladores diseminados en sus ranchos y estancias a cambiar su residencia a un punto central (Mapas 3 y 4).

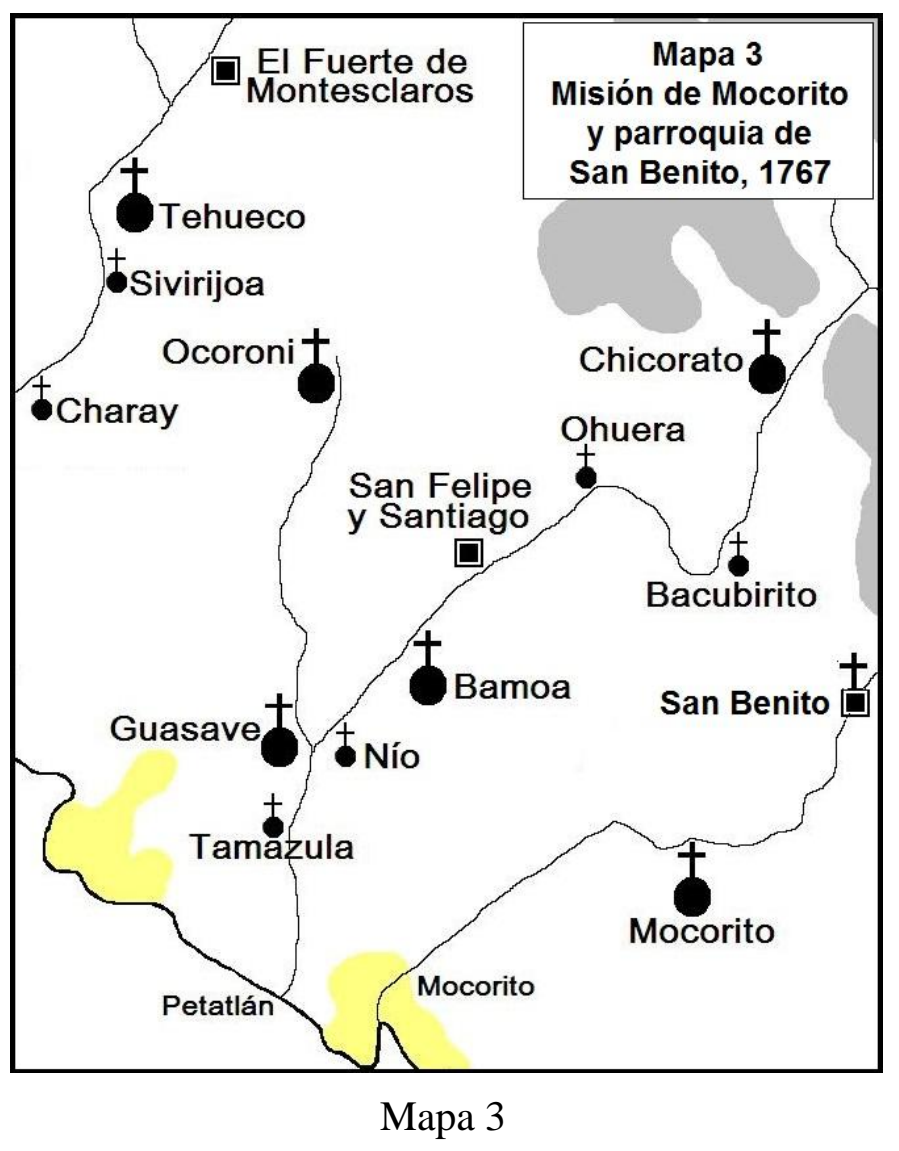

13 "Visita del padre Juan Lorenzo Salgado, remitida al padre provincial Ignacio Calderón, Uiribis, 8 de marzo de 1756", AGN, GD8, Archivo Histórico de Hacienda, Leg. 17, exp. 39, ff. 17. Temporalidades, Misiones, $10 \mathrm{ff}$. 


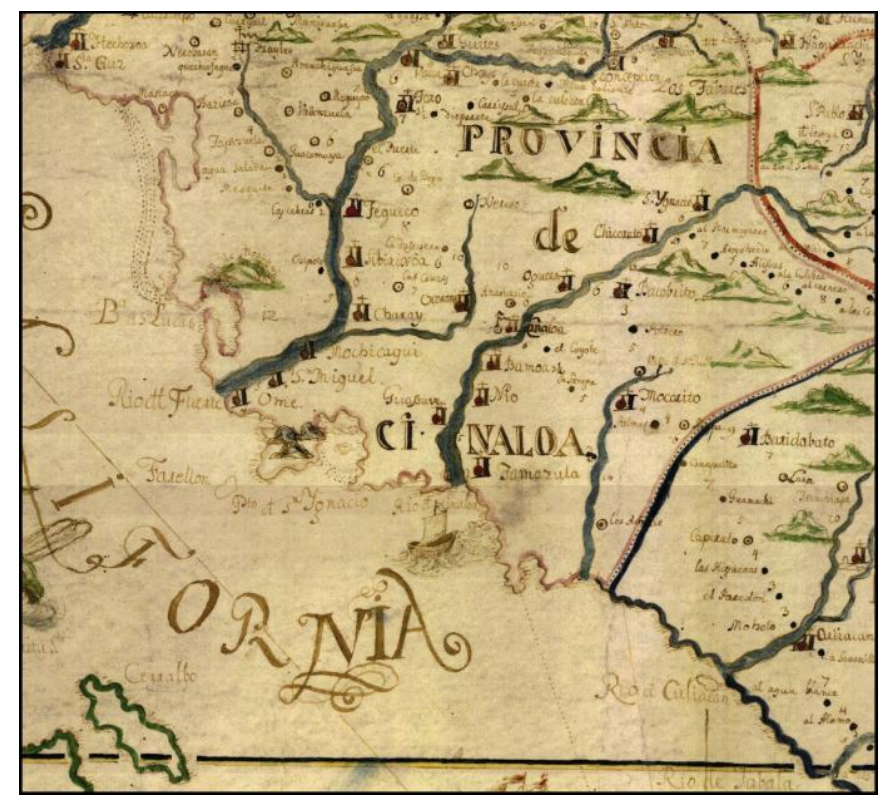

Mapa 4. Detalle de la "Carta cartográfica de las misiones apostólicas que administró antes en Topia Tepehuana, y administra en Nayarit, Tarahumara, Chínipas, Sinaloa, Sonora, Pimería y California de la Compañía de Jesús en la América Septentrional”, Mapoteca Orozco y Berra, Colección Historias parciales 723. Varilla 1, número de control 1162, Manuscrito. Óleo sobre papel. Autor: Compañía de Jesús (Ca. 1753-1767), escala gráfica en leguas.

\section{Patronazgo}

A fines del siglo XVI en Mocorito se inició la construcción de la primera iglesia, que pasó de ser "pajiza", como fueron en su mayoría estos primeros establecimientos, a templo formal, de modo que dos tercios de siglo después, en 1672, el padre Ortiz Zapata habló de "una capaz y buena iglesia con adorno de altares y en ellos imágenes de pincel y de bulto". ${ }^{14}$ (Fig. 3). Desafortunadamente los informes de los misioneros relativos a esta misión son escuetos en datos etnográficos y en estrategias pastorales que nos permitan vincular los bienes religiosos con el desarrollo devocional.

En la "Relación de las misiones que la Compañía tiene en el Reyno y provincia de la Nueva Vizcaya, en la Nueva España”, escrita el año de 1678, con ocasión de la visita general de ellas que por orden del padre provincial Thomas Altamirano hizo el padre visitador Juan Ortiz Zapata, de la misma Compañía, ${ }^{15}$ priva información sobre la institución eclesiástica y el acelerado proceso de aculturación de los indígenas. En este y otros informes se hace hincapié en que en el río Mocorito habitaban grupos pequeños hablantes de lenguas diversas. Y aunque en un principio la lengua mexicana (náhuatl) se tomó como lingua franca por los misioneros, con el tiempo, posiblemente ante las dificultades comunicativas, los indios fueron conminados a tomar el español hasta asumirlo como su lengua vernácula. Remarcamos esto porque a diferencia de pueblos de otras cadenas misionales cercanas como las de los ríos Sinaloa, Mayo y Yaqui, en el río Mocorito ya no se habla lengua indígena.

\footnotetext{
${ }^{14}$ Relación de las misiones..., AGN, Misiones 26, ff 241-269v,

${ }^{15}$ AGN, Misiones 26, fs 241-269v.
} 
El Partido de San Miguel estaba conformado primero por doce pueblos, luego por Mocorito, Orabato y Bacubirito, y finalmente solo quedaron el primero y el último (Velázquez, 1994). La patrona actual de Mocorito es la Virgen de la Concepción (Fig. 4), pero en el siglo XVIII hemos encontrado como patrono a San Miguel Arcángel (quien dio nombre al Partido), y en los inicios de la evangelización a San Pablo en conversión (González Rodríguez, Anzures y Bolaños, 1996, p. 197). La cuestión de los patronazgos no es un asunto menor. En Favores Celestiales, por ejemplo, el misionero Eusebio Francisco Kino deja entrever que la elección del nombre de cada misión no era a capricho y placer del misionero, sino una decisión de padres superiores en la jerarquía ignaciana (Kino, 1985, p. 20). Cuando no era así, se procuraba elegir el día de santo de la fecha de arribo. Bajo esta tesitura, podemos considerar que el cambio de San Pablo a San Miguel, y de San Miguel a la Purísima, obedeció a disposiciones no tomadas a la ligera.

El inventario del padre Espinoza de los Monteros que citaremos posteriormente, da fe de que San Miguel ocupaba el lugar más importante del altar mayor y siempre se refirió a Mocorito como la misión de San Miguel (Fig. 5); sin embargo, sí mencionaba la presencia de la Virgen de la Concepción y ya en 1767 la reconocía como antigua. Esta imagen posee un valor simbólico y taumatúrgico que probablemente haya influido para la determinación de su patronazgo posterior. Así, señalaba el misionero Juan Ortiz Zapata en 1678 que:

En particular en el altar mayor está colocada una de bulto hermosa de la Purísima Vírgen que comúnmente en los contornos la tienen por milagrosa y principalmente que como muchos refieren y todos a una voz afirman habiendo querido en una ocasión el ministro de este partido sacarla de su puesto e iglesia para llevarla a otro partido por ser la imagen muy grande y de madera pesada la hizo aserrar por debajo de la luna que tenía a los pies para dividirla de la peana sobre que estaba fabricada y habiéndose traído una sierra al efecto con advertencia de todos los que asistían que sentían mucho el que se sacase la imagen se quebró y perseverando el ministro en el empeño por especiales motivos que tendría, hizo traer otra y habiéndose di-

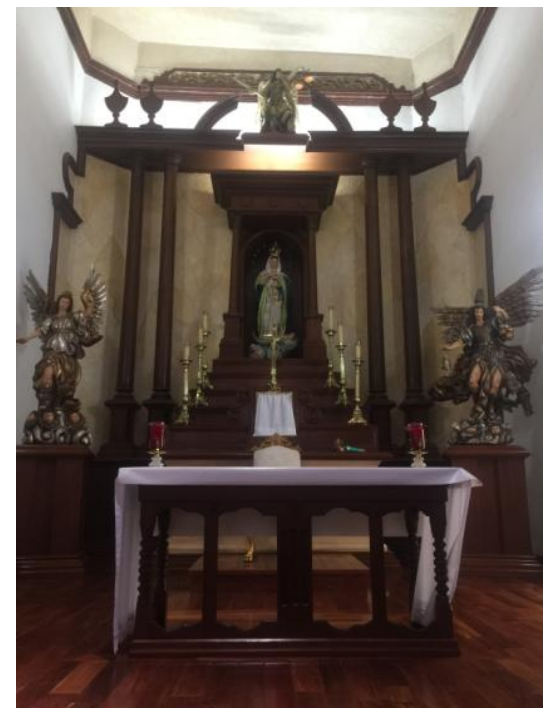

Fig. 3. Altar mayor.

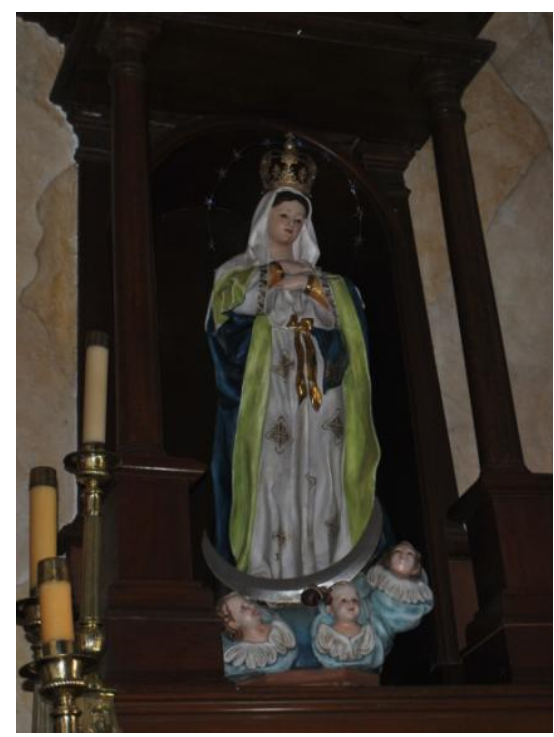

Fig. 4. La Purísima Concepción.

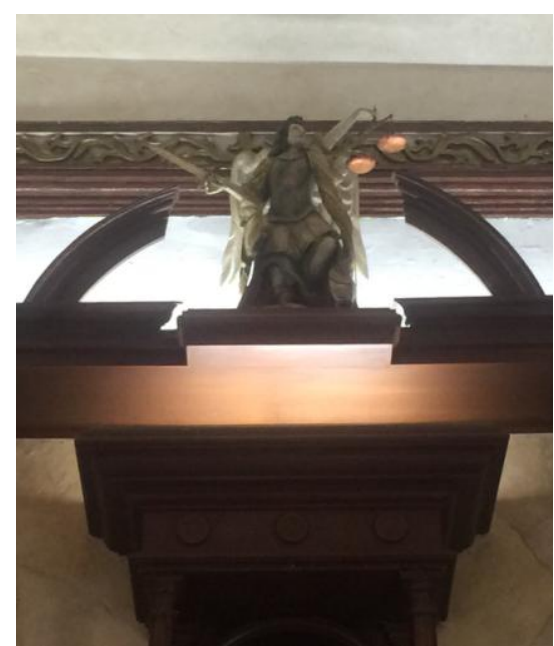

Fig. 5. San Miguel posado sobre el nicho de la Purísima. 
vidido de la peana la remitió al puesto que pretendía, pero el oficial que aserró la imagen no era del pueblo, sino de otro muy distante, antes de llegar a su casa con particular advertencia aun de los mismos indios que lo notaron y refieren, murió. Y el padre poco después, habiendo dado de una mula una caida quedó lisiado y dentro de un año también murió siendo el caso tan notorio y la advertencia y sentimiento de los del pueblo tan grande que habiendo nuevamente venido otro ministro a cuidar de esta misión hubo de disponer el que la imagen se restituyese a su iglesia, altar tabernáculo como se hizo con sumo regocijo y consuelo de todos. ${ }^{16}$

Los dos pueblos, Bacubirito y Mocorito, tenían 395 personas, sorprendentemente muchas de ellas españoles o mestizos, lo que rompe con la especie, como ya señalamos, de que las primeras misiones eran exclusivamente para el servicio religioso de los indígenas. Los indios fungían como sirvientes y criados. Sugiere un informe muy temprano del Partido, signado por el ya mencionado misionero Ortiz Zapata, que el proceso de aculturación de Mocorito fue muy veloz. Mocorito, decía el padre Ortiz:

Dista el uno de sus pueblos que es el de San Pedro Bacubirito siete leguas al sur del pueblo y partido de Chicorato y de la villa de Sinaloa entre sur y oriente doce leguas. La cabecera en la forma que hoy tiene de administración este partido es el pueblo de San Miguel de Mocorito; está situado en puesto llano, fuera de la sierra, distante del mar del sur hasta 10 o 12 leguas, cerca de un río distinto del de Sinaloa. El sitio es apacible. Consta de 72 familias y en ellas se hayan 243 personas de todos sexos y edades de administración. La gente es muy ladina, viven en policía cristiana a modo muy aespañolado. Viven en cuatro parcialidades y distintas lenguas que ya poco conservan congregados. Todos hablan en lengua mexicana de la tierra aún entre sí y muchos hablan la lengua española. Por lo general los naturales son buenos, muestran piedad a las cosas espirituales de la fee y bien de sus almas; acuden con puntualidad y cuidado a la iglesia y su doctrina, tienen una capaz y buena iglesia con adorno de altares y en ellos imágenes de pincel y de bulto. ${ }^{17}$

Bacubirito tuvo por patrón a San Pedro. Luego entonces, sí cabe la posibilidad de que en algún momento la misión de Mocorito, su par, estuviera bajo el patronazgo de San Pablo. Recordemos que Pedro y Pablo aparecen juntos frecuentemente en la iconografía religiosa. El templo de Bacubirito estaba bien ajuareado y su gente parecía acoplarse bien a la vida de los intrusos:

A diez leguas de distancia al norte, reconociendo al oriente de la cabecera, perteneciente hoy a este partido está el pueblo de San Pedro de Bacubirito a orillas del río de Sinaloa situado en puesto llano a las faldas de la sierra. Consta de 51 familias y en ellas se numeran 152 personas de administración. Los naturales son conforme se dijo en el pueblo de San Miguel. La lengua en lo general es la corriente mexicana de la tierra, aunque cual y cual viejo conserva y habla la suya que son cuatro distintas de cuatro parcialidades que allí se han congregado. Tienen una muy buena y capaz iglesia con adorno de altares e imágenes de pincel y de bulto, ornamentos y vasos sagrados para celebrar los divinos oficios con toda decencia y solemnidad. Hay también la capilla de cantores con instrumentos y

\footnotetext{
${ }^{16}$ AGN, Misiones, 26, fs. 241-269v.

${ }^{17}$ Ibid.
} 
acuden los feligreses con puntualidad a la doctrina, mostrando buen afecto a las cosas de la fee, iglesia y bien de las almas. ${ }^{18}$

Ortiz Zapata describe también el entorno extra misional, poniendo énfasis en las actividades productivas y en quiénes usufructuaban las tierras:

En el contorno de este partido, repartidas por todas partes hay hasta 43 estancias, ranchos y trapiches en que tienen sembrada caña, ganados y otras semillas sus dueños, hay en todas hasta 40 o 43 familias de españoles, unos y otros reputados por tales en que se contienen entre padres, hijos y criados 214 personas, e indios que trabajan en ellas 103 , con que son por todas 307 personas. ${ }^{19}$

En septiembre de 1767, es decir recién llevaba a cabo la expulsión, desde la misión de Mocorito el cura Cristóbal Espinosa de los Monteros emitió un documento en el que pormenorizaba los ajuares de la iglesia "y sus agregados" (Fig. 6). El inventario formó parte de una especie de acta de recepción de la iglesia por parte de este padre, cuando fue enviado a Mocorito por el obispo Pedro Tamarón y Romeral.

Es necesario al utilizar los inventarios y de hecho, cualquier documento histórico, establecer una crítica de carácter historiográfico. Así debemos preguntarnos primeramente por las intenciones de quien lo firma. En este caso, consideramos que el padre Espinosa tenía muy claro que ante la expatriación ignaciana, su responsabilidad era muy alta y debía levantar un catálogo pormenorizado. En cambio, el informe general que realizó a fines del siglo XVIII el obispo

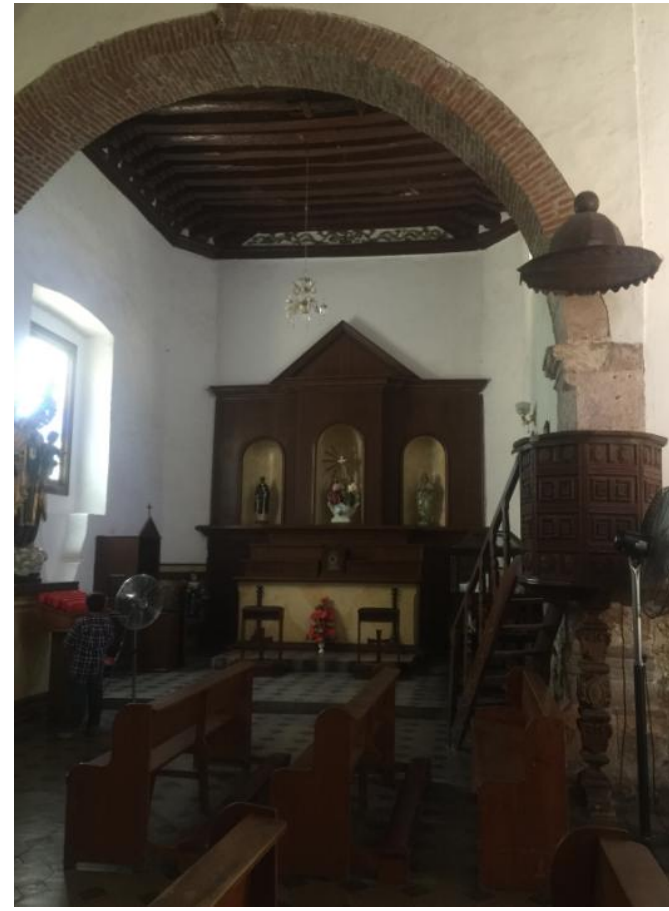

Fig. 6. Capilla lateral y púlpito.

Fr. Antonio de los Reyes es escueto y pesimista, ya que remarca el estado deplorable de las misiones para justificar su desmantelamiento y la entrada del proceso de secularización, por lo que casi todas las misiones se reportan en estado ruinoso, sin techo y sin indios qué misionar, mientras que durante el protocolo del padre Espinosa de los Monteros, la situación era diferente, Mocorito se aprecia como una misión en bonanza y estable. De hecho, desde el informe de Ortiz Zapata del año 1678, se sabía que:

Está esta iglesia muy bien pertrechada de buenos ornamentos, lámpara y blandones de plata y de otras alhajas y vasos sagrados para celebrar no solo con decencia sino también con especial ornato las fiestas y divinos oficios. Hay una muy buena capilla de cantores con todos instrumentos y hacense con mucha solemnidad y mucho concurso de la gente española de los contornos las fiestas. ${ }^{20}$

\footnotetext{
${ }^{18}$ Ibid.

${ }^{19}$ Ibid.

${ }^{20}$ Ibid.
}

41 Raquel Padilla Ramos y Gilberto López Castillo. Mocorito y San Benito... 28-47. 
La segunda crítica que estableceríamos al uso de los inventarios como fuentes primarias es que al momento no tenemos gran cantidad de ellos para esta región, lo que no nos permite dar continuidad del todo a los bienes muebles, a los patronazgos y a las devociones religiosas. Tercera, en términos devocionales el contenido de los inventarios no es determinante para adjudicar fervores por ciertos santos o vírgenes, ya que pudo haber imágenes que a pesar de estar presentes en algún templo, pudieron no ser veneradas (Bojórquez Martínez, Martínez Álvarez y Padilla Ramos, 2003, pp. 179-193). Ese parece ser el caso de la conversión de San Pablo, posible patrono original de Mocorito.

En resumen podemos decir que la casa vivienda de la misión de Mocorito era de piedra y cal, tenía un largo corredor que daba a la calle con pilares, una antesala que la hacía de oficina y corredores internos. Sus ventanas estaban protegidas con verjas de fierro y casi todas las puertas tenían llaves, lo que nos habla que la seguridad era asunto importante. La sala era grande y tenía una alcoba, y dentro de esta, un cuarto que hacía las veces de almacén. No podría faltar el corral tapiado que circunvalaba toda la casa y un corralito para las gallinas. ${ }^{21}$

La descripción del edificio del templo por fortuna corresponde básicamente a lo que tenemos hoy: fábrica de cal y canto, crucero que remata en dos capillas "que forman un crucero a base de arcos de medio punto, los cuales se apoyan en pilastras que existen en las esquinas" (Santos, 2015: 129) ${ }^{22}$ techo de vigas labradas, coro y una torre de dos cuerpos (de las pocas que presentaban esta característica) con una campana grande y cuatro medianas, justo el número que sobrevive pero desafortunadamente, todas refundidas (Fig. 7). Las descripciones del siglo XVIII se refieren a la iglesia como "primorosísima" y "amplísima" (Bargellini, 1992, p. 115). Víctor Joel Santos considera que el templo de Mocorito es "el inmueble jesuítico mejor conservado de las exmisiones en la entidad, data del siglo XVIII y presenta remodelaciones de los siglos XIX y XX" (Santos, 2015: 20). De igual modo, se le describe como imponente y masiva, y se señala que tiene cierto aspecto de fortaleza por sus muros almenados (Bargellini, 1992, p. 127) (Fig. 8).

Evidentemente los bienes muebles sí han cambiado. Por ejemplo, el altar mayor que estaba conformado por un colateral de ladrillo pintado de colores con San Miguel Arcángel de bulto y seis lienzos, una imagen de San Juan Nepomuceno y otra de Santa Catarina, y un Cristo de bronce entre otras cosas, ahora presenta únicamente a la Purísima flanqueada por los Arcángeles San Rafael y San Gabriel, y arriba, San Miguel, quien diera nombre a la misión. Destacaba en este altar la imagen ya mencionada de talla grande (ya vieja, dice el inventario) de Nuestra Señora de la Concepción con su corona de plata. Consideramos que es la misma que ahora se encuentra y que en total eran tres los colaterales de ladrillo pintado (Bargellini, 1992, p. 113).

En una de las capillas había un altar dedicado al señor San José con el Niño de bulto, cinco lienzos y otros objetos, y otro altar con los santos de la Pasión. Había asimismo dos imágenes pequeñas de la Virgen y dos relicarios sobredorados, una pila bautismal grande de piedra con tapa de madera, vasos sagrados de plata, un San Ignacio y un San Francisco Xavier grandes de talla y muchos objetos de carácter litúrgico los cuales al no reportarse como viejos o en mal estado, inferimos que al momento se conser-

\footnotetext{
${ }^{21}$ Archivo de la Parroquia de Mocorito: SEC Sacramental, Bautismos, vol. 6: 1712-1791, Caja 1. Del padre Cristóbal Espinosa de los Monteros, al obispo Pedro Tamarón y Romeral. Informe de recepción del Templo de Mocorito, 18 de septiembre de 1767.
}

${ }^{22}$ Santos, 2015, p. 129 
vaban bien.

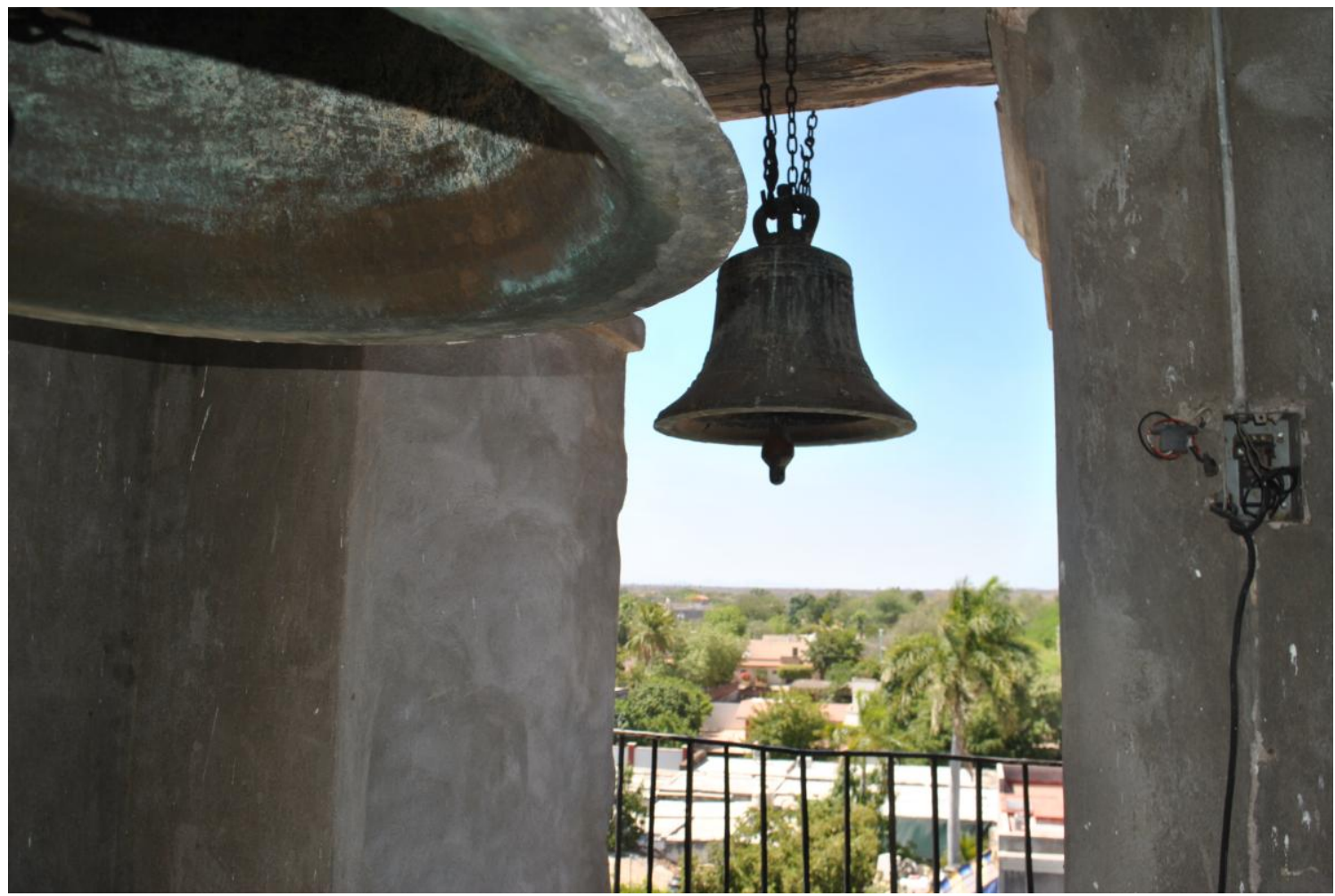

Fig. 7. Campanas.

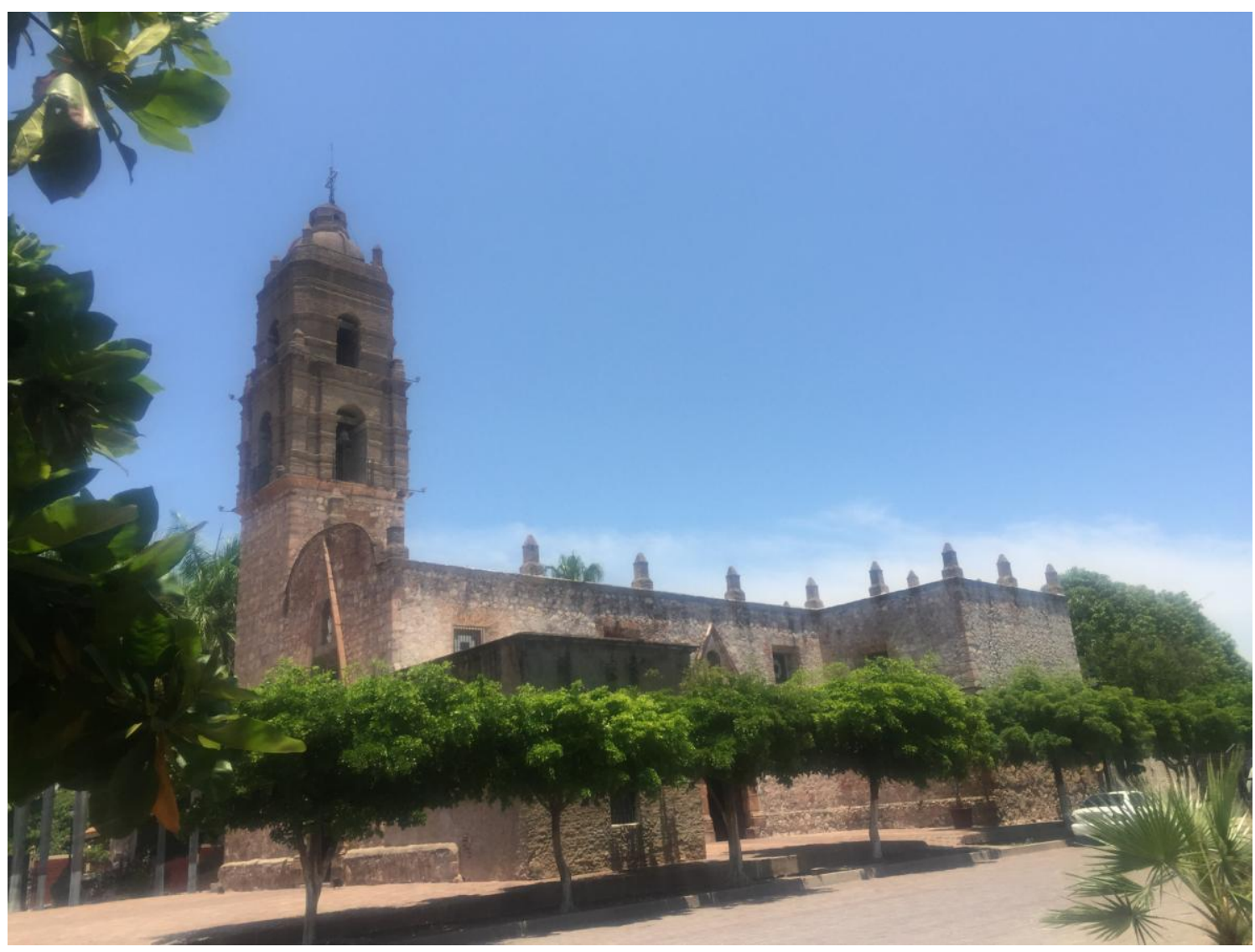

Fig. 8. Templo de la Purísima Concepción de Mocorito. 
La sacristía estaba muy bien equipada tanto con ornamentos como paramentos. Se registró un confesionario y los libros viejos y nuevos de la administración de Mocorito y Bacubirito. En este último pueblo el inventario fue levantado por el comisario Esteban Moreno de León, quien describió la iglesia como casi demolida y en riesgo, mas sus bienes muebles en buen estado: la Santísima Señora, Santa Ana y la Virgen y San Pedro de bulto, varios lienzos y vasos sagrados. ${ }^{23}$

La iglesia de Mocorito impactaba por su belleza y calidad. Por 1750 el misionero jesuita Jacobo Baegert en tránsito de la Ciudad de México al Río Yaqui, anotó que "desde Tepique no hay otra construcción de la misma manera, de piedra y mezcla". Ya en el proceso de secularización, el obispo Fr. Antonio de los Reyes reconocía aún que "la iglesia y casa son de buena fábrica con bóvedas de ladrillo y cal" y que se sostenía gracias a un rancho de ganado mayor. Afirmaba asimismo que la gran extensión del Curato impedía una apropiada cobertura del trabajo pastoral. ${ }^{24}$

\section{Conclusiones}

Mediante las fuentes y el análisis realizado a lo largo de este artículo, podemos perfilar varias conclusiones, la primera tiene que ver con el hecho que Mocorito tiene hasta hoy el templo misional mejor conservado del estado de Sinaloa. Consideramos que ello está vinculado a la presencia de pobladores hispanos desde épocas tempranas ya que en general todo el entorno misional del río Évora se caracterizó por la estrecha relación entre los jesuitas y los pobladores hispanos que acudían a la misión tal como si fuera una parroquia y era ahí donde recibían los sacramentos del bautizo y del matrimonio y donde eran sepultados. Por lo demás, el misionero no solo administraba a los indios en su asentamiento central, sino que acudía a los ranchos y estancias para atender a unos y otros. Este que era un problema para el Obispado de Durango fue un tema irresuelto hasta antes de 1767 por carecer de suficientes clérigos para atender aquellos espacios.

Esta participación hispana en la vida misional habría contribuido para el mantenimiento y conservación de la misión, incluso después de creada la parroquia de San Benito. Recordemos que desde mediados del siglo XVIII el nuevo templo, que es el actual, llamaba la atención de propios y extraños por su magnificencia y que el recinto arquitectónico conserva relativamente su originalidad a excepción de los huertos y el tapiado, aunque los bienes muebles han sufrido gran merma. En este sentido urgen levantamientos de inventarios en la zona, para saber si, a pesar de la pérdida de objetos, es de las que conserva más y mejores imágenes y ajuares de culto. Otro de los aspectos es que la misión de Mocorito pudo sufrir un proceso acelerado de aculturación por la diversidad etnolingüística, es decir, que en tanto la identidad étnica fuese tan variada, definirse con una nueva y uniforme identidad mexicanizada y luego españolizada, contribuía a un mejor entendimiento. En fin, la misión jesuita en el río Évora se erige como un excelente escenario para el estudio de la misión de Sinaloa gracias a las diversas características que la hacen especial en el conjunto de la Provincia Mexicana de la Compañía de Jesús.

\footnotetext{
${ }^{23}$ Archivo de la Parroquia de Mocorito: SEC Sacramental, Bautismos, vol. 6: 1712-1791, Caja 1. Del comisario Esteban Moreno de León, al obispo Pedro Tamarón y Romeral. Inventario, 18 de septiembre de 1767.

${ }^{24}$ Prensa, p. 24, "Jornada Sinaloense”, San Antonio, Texas, Mayo, 29,1938.
} 


\section{Anexo 1. Poblamiento hispano de San Benito}

\begin{tabular}{|c|c|c|}
\hline $\begin{array}{l}\text { Antigüedad } \\
\text { estimada }\end{array}$ & Nombre & Propietario \\
\hline 1690 & Rojas Potrero de & $\begin{array}{l}\text { Ávila Juan de, Bernal Angelina (2) Ignacio Sepúl- } \\
\text { veda G (3) }\end{array}$ \\
\hline 1699 & Tule, El & Terrazas, Juan Ignacio de Y Dionicia Terrazas \\
\hline 1699 & Tasajera & $\begin{array}{l}\text { Leyva, don Juan de, Castro, Don Pedro de Y Do- } \\
\text { mingo de Leyva ( } 2 \text { ) }\end{array}$ \\
\hline 1699 & Cahuinaguato P. De & Colegio de Sinaloa y Sánchez, D. Pedro Luis (2) \\
\hline 1699 & Roxas, Palmar de & Sepúlveda, don Francisco Xavier de \\
\hline 1705 & Aguacaliente & $\begin{array}{l}\text { Gues, Ygnacio de, Ma López de Guzmán (2) y } \\
\text { Camacho D Agustin (3) }\end{array}$ \\
\hline 1710 & Caytime, SJ & Inzunza, D Diego \\
\hline 1711 & Huerta, P de S Nicolás & Guez doña Agustina \\
\hline 1716 & Carrizalejo, P. del & Gasteategui, don Juan de \\
\hline 1716 & Laxas, Las & Inzunza, Juan Francisco de \\
\hline 1719 & Bárbara, Sta. & Perez de Figueroa (Hers.) y D Fca. X de Vla \\
\hline 1722 & Aguacaliente $\mathrm{P}$ del & Angulo, D Miguel Isidro, Juan Camacho y cop. \\
\hline 1722 & Aguacaliente & Castro, don Pedro Bernardo de \\
\hline 1724 & $\begin{array}{l}\text { Tebuche, } \mathrm{P} \text { de, } \mathrm{SJ} \text { de los Sobe- } \\
\text { ranes y Sta Rosa }\end{array}$ & Azcárraga, D Sebastián Antonio de \\
\hline 1725 & Bárbara, S & Valenzuela, D Juan Ygnacio \\
\hline 1725 & Gatos, SJ de los & Álvarez de Azevedo, Juan \\
\hline 1727 & $\begin{array}{l}\text { Maripeto, Maborato y Chapoti- } \\
\text { llo y el Agua de J. de }\end{array}$ & Angulo don Joseph e Ylarregui, Da. Ygnacia de (2) \\
\hline 1728 & $\begin{array}{l}\text { Rivera del Río Mocorito, San } \\
\text { Joseph de la }\end{array}$ & Soberanes, Pedro de \\
\hline 1728 & $\begin{array}{l}\text { Yacochito y San Pedro del } \\
\text { Guamuchil }\end{array}$ & López de Ayala don Pedro \\
\hline 1728 & Canaporito & Madrid de la Rocha, D Andrés \\
\hline 1732 & Acatita, San Miguel de & Sánchez, Greogorio \\
\hline 1735 & Calabaza, sitio de & Valenzuela, don Joaquín de \\
\hline 1735 & $\begin{array}{l}\text { Alhuey o Potrero de los Solda- } \\
\text { dos }\end{array}$ & Presidio de Sinaloa \\
\hline 1736 & Potrero, El y Las Canastas & Bohórquez, D Juan \\
\hline
\end{tabular}




\begin{tabular}{|c|c|c|}
\hline 1736 & $\begin{array}{l}\text { Bautista SJ Valle de y Potrero } \\
\text { de las Perdices }\end{array}$ & Sánchez, Gregorio \\
\hline 1742 & $\begin{array}{l}\text { Ylama, Mirigüeto, SJ del Ga- } \\
\text { vilán y el Potrerillo }\end{array}$ & $\begin{array}{l}\text { Sánchez, don José Manuel, don Pasqual y don Ma- } \\
\text { riano }\end{array}$ \\
\hline 1743 & Baromena, Puesto de & Báez, Ygnacio María \\
\hline 1751 & Bacosira, Puesto de & Angulo, D J Ygnacio y D J Benito López \\
\hline 1762 & $\begin{array}{l}\text { Batamotita, Santa Ana de (Bue- } \\
\text { navista) }\end{array}$ & Rocha, D J Vicente, D J Ignacio y D Joaquin \\
\hline 1762 & Palmar & Sánchez, don Guillermo \\
\hline 1765 & Turaquito & González de la Vega, D Francisco \\
\hline
\end{tabular}

Fuente: López Castillo, 2010, pp. 226-234.

\section{Referencias}

\section{Documentales}

Archivo Histórico de la Provincia Mexicana de la Compañía de Jesús

Archivo General de la Nación AGN, Misiones y Temporalidades.

Archivo Parroquial de Mocorito, Sacramental.

Archivo de la Real Audiencia de Guadalajara, Ramo Civil.

Archivum Romanum Societatis Iesu, Fondo México.

Mapoteca Manuel Orozco y Berra, México.

\section{Bibliográficas}

Bargellini C. (1992). "La arquitectura religiosa de Sinaloa. Estudio documental". Regionalización en el arte. Teoría y praxis. José Guadalupe Victoria, Elisa Vargas Lugo, María Teresa Uriarte (Comp.). México: Gobierno del Estado de Sinaloa, UNAM, Instituto de Investigaciones Estéticas.

Bojórquez Martínez N., Martínez L. R. y Padilla Ramos, R. (2004). "La catequesis jesuita según los inventarios de los templos de culto yaqui”. Misiones del Noroeste. Culiacán: FORCA.

Borrero S. M. del V. (2004). Fundación y primeros años de la gobernación de Sonora y Sinaloa 1732-1750. Hermosillo: El Colegio de Sonora.

Burrus E. J. y Zubillaga F. (Coords.) (1982). Misiones mexicanas de la Compañía de Jesús 1618-1745 (Cartas e informes conservados en la Colección Mateu). Madrid: Porrúa, Colección Chimalistac 41.

(Ed.) (1986). El noroeste de México. Documentos sobre las misiones jesuíticas 1600-1769, México, UNAM. 
Carrillo Rojas, A. et. al. (2012). Historia del agua en Sinaloa. Siglo XX (Catálogo de documentos históricos del Archivo Histórico del Agua). México: Archivo Histórico del Agua, CONAGUA, CIESAS, Facultad de Historia-UAS. C.D.

Gerhard, P. (1996). La frontera norte de la Nueva España. México: Universidad Nacional Autónoma de México-Instituto de Investigaciones Históricas.

González Rodríguez, L. y Anzures y Bolaños, M. del C. (1996). "Martín Pérez y la etnografía de Sinaloa a fines del siglo XVI y principios del siglo XVII", en Estudios de Historia novohispana. Pp. 171-213.

Gutiérrez Casillas, J. (1975). Diccionario Biobibliográfico de la Compañía de Jesús en México, Tomo XIV. México: Editorial Tradición.

Hausberger, B. (2015). Miradas a la misión jesuita en Nueva España. México: El Colegio de México.

Kino, E. F. (1985). Favores Celestiales. Crónica de la Pimería Alta. Hermosillo, Gobierno del Estado de Sonora.

López Castillo, G. (2010). El poblamiento en tierra de indios cahitas. Transformaciones de la territorialidad en el contexto de las misiones jesuitas, 1591-1790. México, Siglo XXI Editores-El Colegio de Sinaloa.

Mocorito. Vol. 12 de Monografía. (1990). Sinaloa: Secretaría de Hacienda Pública y Tesorería / Gobierno del estado de Sinaloa.

Moreno de Alba J. G. (Prólogo). (1998). Arte de la lengua cahita. México: Siglo XXI Editores-DIFOCUR: 9-18.

Navarro García L. (1992). Sonora y Sinaloa en el siglo XVII. México: Siglo XXI Editores.

Ortelio A. (1579). Theatrum Orbis Terrarum. Antverpiae: exoficina plantiniana.

Pérez de Ribas, A. (1992) [1645]. Historia de los triumphos de nuestra santa fee entre gentes las más fieras y bárbaras del nuevo orbe, estudio introductorio, apéndices y notas de Ignacio Guzmán Betancourt, México, Siglo XXI EditoresDIFOCUR.

Rodríguez Gallardo, J. R. (1975) [1750]. Informe sobre Sinaloa y Sonora 1750. México: Archivo General de la Nación- Archivo Histórico de Hacienda, Edición crítica de Germán Viveros.

Santos V. J. (2015). Las misiones jesuíticas de Sinaloa. Pasado y presente de los monumentos históricos. Culiacán: Centro INAH Sinaloa.

Velázquez J. R. (1994). Apuntes de Mocorito. Culiacán: Colegio de Bachilleres del Estado de Sinaloa.

Zubillaga, F. (2001). "Velasco, Juan Bautista, misionero, padre lengua". En: O’Neill, C. E. y Domínguez, J. M. Diccionario histórico de la Compañía de Jesús Biográfico Temático IV, Roma-Madrid: Institutum Historicum S. I.-Universidad Pontificia Comillas. 